\title{
An Investigation of the Seaweeds within a Marked Zone of the Shore at Aberystwyth, during the Year 1933-34.
}

(With special reference to the Use of the Spores as food for Oyster Larvæ).

\author{
By
}

Edith A. Lewis, M.Sc.

From the Botanical Department, University College, Aberystwyth.

\section{INTRODUCTION.}

THE following piece of research has been undertaken at the suggestion of the Conway Fisheries Research Station of the Ministry of Agriculture and Fisheries.

For some years experiments have been in progress at Conway in connection with oyster breeding. During the oyster season, from May to August, when the tanks of the Research Station are not being used for mussel cleansing, cultural work on the oyster (Ostrea edulis) has been carried out. One of the greatest difficulties is the feeding of the larvæ in the free swimming state and this problem affects both tank culture and culture on a smaller scale. In some years a settlement of spat has taken place, but it is not known what conditions made that phenomenon possible. It has been suggested that the available food supply might be of importance, since both detritus on the one hand, and seaweed spores and gametes on the other, have been regarded as constituting the food of larvæ (Martin, 1923). As nothing over $10 \mu$ can be ingested by the larvæ, there is a limit to the spores and gametes which may be used. The carpospores of the Rhodophyceæ will obviously be too large, and in the brown and green Algæ the range of possible food bodies will be restricted.

Ladd (1933) has investigated the possibility of using Enteromorpha zoospores for the purpose, but owing to the restrictions necessarily afforded by any one genus, it was felt that it was imperative to make careful observations on a portion of shore over a set period and to study the times of fruiting of some of the commoner algæ. So little has been written on the subject that data have not been available which would enable an investigator to see what suitable material might be obtained at any particular time of year.

A strip of shore was chosen on the college rocks at Aberystwyth. It 
was marked and was selected so as to include as far as possible the seaweeds available at Conway which could be used in the above connection.

The species present were listed and a record was kept of their epiphytes and of their fruiting periods.

The records of the succession of species occurring within the area were taken monthly from September, 1933, to August, 1934. The Rhodophyceæ found in the strip were added to the list for the sake of completeness, although they appear to be of no direct use in connection with the problem at Conway.

A complete ecological account of the vegetation has not been attempted, as the collecting of the records themselves was a considerable task. A table is given showing the fruiting periods of each recorded species.

\section{The Fruiting Periods of the Species Recorded.}

After records had been made of the species, it became necessary to examine carefully their fruiting periods, and to prepare a table so that workers at Conway might be able to see what plants were fruiting at any particular time when food might be needed for the oyster larvæ. In the accompanying table is shown $(a)$ the duration of the fruiting period, and (b) the type of fruiting body.

It is hoped that this table will be of value in showing the wide range of time over which certain species fruit and the large number of species which can be considered in connection with the oyster cultural work. In point of time, the species which can be used are those that fruit from May to August, i.e. during the oyster breeding season. However, not all the species that are fruiting during these months can be used as the spores must be of the required size, i.e. under $10 \mu$. The following are the spores which could be used if sufficient material were available :-

1. Zoospores of Enteromorpha compressa and Ulva lactuca.

2. Gametes of Cladophora rupestris, Cladophora gracilis and Cladophora flexuosa.

3. Sperms of Fucus vesiculosus, Fucus serratus and Fucus spiralis.

4. Spores of the unilocular sporangia of Pilayella littoralis, Ectocarpus ovatus, Ectocarpus repens, Myrionema strangulans and Chorda Filum.

5. Spores of the plurilocular sporangia of Pilayella littoralis, Ectocarpus ovatus and Ectocarpus repens.

6. Spermatia of Polysiphonia nigrescens and Polysiphonia fastigiata. These would probably be of little use as they have no food reserve.

The eggs of the species of Fucus and the carpospores and tetraspores of 


\section{TABLe I.}

\section{Type of Fruiting Body and Duration of. Fruiting.}

Zoosporangia.

1. Enteromorpha compressa

2. Ulva lactuca

3. Laminaria digitati

4. Laminaria sacharina

Gametangia.

1. Fucus spiralis

2. Fucus serratus

3. Fucus vesiculosus

4. Ascophyllum nodosum

5. Halidrys siliguosa

6. Cladophora rupestri

7. Cladophora gracilis

8. Cladophora flexuosa (?)

Unilocular sporangia.

1. Cladostephus spongiosus

2. Pilayella littoralis

3. Sphacelaria cirrhosa

4. Ectocarpus ovatus .

5. Ectocarpus repens

6. Myrionema strangulans

7. Castagnea virescens

8. Chorda Filum

Plurilocular sporangia.

1. Cladostephus spongiosus

2. Pilayella littoralis.

3. Scytosiphon lomentarius

4. Ectocarpus ovatus

5. Ectocarpus ovatus

Tetrasporangia or Monosporangia.

1. Hildenbrandtia prototypus

Dictyota dichotoma

. Dumontia incrassata

Plocamium coccineum

5. Ahnfeltia plicata

6. Chondrus crispus .

7. Lithothamnion Lenorman

9. Palyides rotundus

10. Ceramium rubrum

11. Ceramium strictum

12. Ceramium flabelligerum

13. Rhodymenia palmata

14. Rhodomela subfusca

15. Polysiphonia fastigiata

. Polysiphonia nigrescens.

16. Polysiphonia nigrescens

17. Polysiphonia urceolata

18. Grateloupia filicina

19. Lomentaria articulata

Procarps and Cystocarps.

1. Polvides rotundus

2. Phyllophora membranifolia

3. Phyllophora Trailli

5. Plocamium coccineum

5. Plocamium coccine

7. Ceramium rubrum

7. Ceramium strictum

8. Ceramium flabelligerum .

10. Polysiphonia nigrescens.

Spermatangia.

1. Rhodomela subfusca

2. Polysiphonia fastigiata

3. Polysiphonia nigrescens .

4. Furcellaria fastigiata

+ Maximum fruiting period.

- Intermittent fruiting.
Months of the Year.

Jan. Feb. Mar. April. May. June. July. Aug. Sept. Oct. Nov. Dec.

$\begin{array}{llllllllll}- & - & - & + & + & + & + & + & - & -\end{array}$

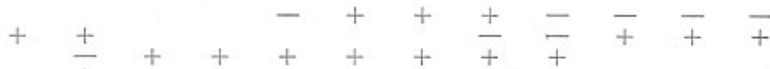

$+\quad+$

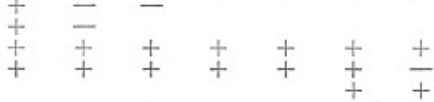

$+\underset{+}{+}++$

$\begin{array}{ll}+ & + \\ + & + \\ + & +\end{array}$

$+\quad+\quad+$

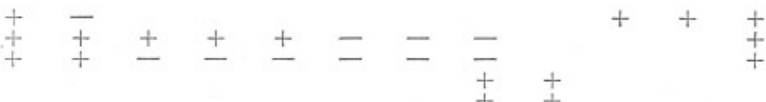

$+\quad+$

$+\quad+\quad+$

$-++$

$-$

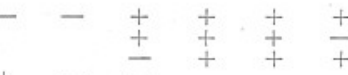

$-+$

$++ \pm+\infty+\infty+\infty+$

$++-\quad+\quad+\quad+\quad+\infty+$

$$
\begin{aligned}
& \begin{array}{lll}
+ & + & -
\end{array}+ \\
& + \pm+
\end{aligned}
$$


the Rhodophyceæ cannot be considered as they are too large to be ingested by the larvæ.

It is evident from the tables that a correlation occurs between the position of the various algæ on the shore and their respective times of fruiting. Most of the algæ near high-water mark are fruiting in summer e.g. Fucus spiralis, Enteromorpha compressa, Ulva lactuca and the species of Cladophora. In winter Fucus serratus, Laminaria digitata and Laminaria saccharina are fruiting. These grow near low-water mark. Certain of the Rhodophyceæ, e.g. Rhodymenia palmata and Plocamium coccineum which grow near low-water mark are also fruiting at this season. Species that grow in the mid-tidal zone reach the maximum of their fruiting in the seasons between, e.g. Ascophyllum nodosum (spring), Fucus vesiculosus (spring) and Cladostephus spongiosus (autumn). This phenomenon was noticed formerly by Harris working at Aberystwyth on the fruiting periods of Laminaria and is mentioned by her in a thesis. The present work, however, extends the observations to a larger number of genera.

\section{Conclusions.}

The ascertaining of the fruiting period of a number of plants gives an indication of what species are available for consideration as food for oyster larvæ. Although the Rhodophyceæ are not in themselves of use, it is realised that the smaller green and brown algæ which are often epiphytic on them may prove very important. Species like Pringsheimia scutata Reinke, Endoderma viride Lagerh., and Ectocarpus ovatus may be taken as examples. These smaller species may prove very difficult to handle, but if they can be used a much wider range of food would be available and the chances of obtaining food at any particular time might be greatly increased.

The tabulated list of the fruiting periods gives the species that are fruiting from May to August, i.e. in the oyster-breeding season. Any of the species, which fruit at this period could be used, provided the motile bodies produced were of a size suitable for ingestion by the larvæ. A list of the spores that could be used is also given.

Having shown which species are available, the next step seems to be a detailed investigation of conditions most favourable to the discharge of spores and gametes. It would be necessary to be able to produce these conditions in the laboratory so that food might be provided in quantity at any given time. An adequate culture method by which experiments could be performed on plants at the same stages of development would be necessary.

Experiments on Enteromorpha have been carried out formerly in the department of Botany of the University College of Wales, Aberystwyth. 
The results suggest that there is a periodicity in the ejection of the spores as the present writer believes to be the case in Pilayella littoralis. Fucus serratus and Ascophyllum nodosum will freely eject their sperms in a damp chamber, though even here there is a possibility that a maximum is reached periodically. If the periodicity could be ascertained and definitely established, the plants could be collected at suitable intervals. Then with the knowledge of the fruiting times of suitable plants, a supply of material might be kept available.

It is realised that some of the smaller algæ might not be suitable for feeding spat in large tanks, but provision must also be made for work in culture tanks where a smaller amount of food would need to be available.

It is hoped that the information now obtained on the fruiting periods of many common algæ may at all events prove a small contribution to the ultimate solution of the problem.

\section{BIBLIOGRAPHY.}

Baker, S. M. 1909-10. On the Causes of the Zoning of Brown Seaweeds on the seashore. New Phytologist. Vols. VIII and IX.

Batten, L., 1923. The genus Polysiphonia. Journ. Linn. Soc. Vol. XLVI.

Batters, E. A. L., and Holmes, E. M. 1890-91. A revised list of the British Marine Algæ. Ann. of Bot., Vol. V.

Batters, E. A. L. 1895. Some New British Algæ. Ann. of Bot., Vol. IX. 1899. A List of the Marine Algæ of Berwick on Tweed. Berwick Nat. Club Transact.

Chater, E. H. 1927. On the distribution of the larger Brown Algæ in Aberdeenshire Estuaries. Trans. and Proc. of the Bot. Soc. of Edinburgh. Vol. XXIX, Pt. IV.

Cotton, A. D. 1912a. Clare Island Survey. Pt. 15. Marine Algæ. Proc. Roy. Irish Acad., Vol. XXXI.

— 1914. Distribution of Certain British Algæ. J. of Bot., Vol. 52.

Darbishire, O. V. 1895. Die Phyllophora Arten. der Westlichen Ostsee Deutschen Anteils. Kiel, Schmidt \& Klaunig.

Harvey, W. H. 1846-51. Phycologia Britannica. Vols. I-IV. London, Reeve and Benham.

Knight, M. K., and Parke, M. W. 1931. Manx Algæ. Liverpool, University Press. 
KYLIN, H. 1923. Studien über die Entwicklungs-geschichte der Florideen. Kungl. Svenska. Vetenshaps akademiens Hadlingar. Band 63. No. 11, Stockholm.

LADD, J. C. 1933. Experiments on discharge of Zoospores and gametes of Enteromorpha. Hons. Thesis, University College of Wales, Aberystwyth.

Martin, G. W. 1923. "Food of the Oyster." Bot. Gaz. Vol. 75.

Newton, L. 1931. "A Handbook of the British Seaweeds." British Museum (Natural History).

Oltmanns, F. 1922. Morphologie und Biologie der Algen. 2 Auf., II, Band.

Rees, T. K. 1928. Fruiting Periods of the Brown Seaweeds. Proc. of Swansea Sci. and Field Nat. Soc., Vol. I, Pt. 2.

1929. Marine Algæ of the Coast of Wales. Journ. Bot., Vol. 67, No. 793 .

1931. Preliminary observations on the Phæophyceæ of Lough Hyne. Journ. Ecol., Vol. XIX, No. 2.

Rosenvinge, L. K. 1909. The Marine Algæ of Denmark. Memories de l'Academie Royale des Sciences et des Lettres de Denmark, Copenhagen. $7^{\mathrm{me}}$ ser. Sect. des Sc., Vol. VII.

__ 1917. No. 2, ibid., Vol. VII.

— 1923-24. No. 3, ibid., Vol. VII.

Sjostedt, L. G. 1926. "Floridean Studies." Lund. Univ. Arsskrift N.F. Avd. 2, Bd. 22. Kungl. Fysiografiska Sällskapets Handlingar.

Williams, J. L. 1905. "Studies in the Dictyotaceæ." Ann. of Bot., Vol. XIX, No. 76 . 